\title{
W programach Interreg na lata 2021-2027 dużo się dzieje - warto być na bieżąco
}

Interreg Europa Środkowa (IEŚ)

W programie współpracy transnarodowej Interreg Europa Środkowa 2021-2027 trwa obecnie - otwarty 15 listopada 2021 r. - I nabór wniosków. Propozycje projektowe będzie można składać do 23 lutego 2022 r. Potencjalni beneficjenci, przygotowując projekty, moga brać pod uwagę wszystkie priorytety i cele szczegółowe programu - na tym etapie jego realizacji nie wprowadzono ograniczeń tematycznych. Budżet I naboru po stronie alokacji z Europejskiego Funduszu Rozwoju Regionalnego zamyka się orientacyjnie łączną kwotą 72 mln euro. Warto jednak zwrócić uwagę, że alokacja nie jest rozłożona równomiernie na poszczególne priorytety, co na ogół nie pozostaje bez wpływu na postawy wnioskodawców.

Dla przypomnienia, program IEŚ ${ }^{1}$ jest realizowany, tak jak dotychczas, na obszarze 9 państw: Polski, Czech, Słowacji, Węgier, Austrii, Słowenii, Chorwacji oraz części Niemiec i Włoch. W stosunku do perspektywy 2014-2020 nastapiła niewielka zmiana zasięgu geograficznego, poprzez powiększenie obszaru programu o niemiecki region Brunszwik. Budżet programu wynosi 224,6 mln euro z EFRR. Dofinansowanie dla beneficjentów w formie refundacji to kwota do $80 \%$ poniesionych kosztów kwalifikowalnych. Program wspiera 4 priorytety oraz 9 celów szczegółowych. Priorytety dotyczą współpracy na rzecz: (1) inteligentnej, (2) bardziej zielonej i (3) lepiej połączonej Europy Środkowej oraz (4) poprawy systemu zarządzania współpraca w tym regionie Europy. Alokacja na priorytety w I naborze wynosi odpowiednio: 22, 36, 7 i 7 mln euro.

Beneficjentami programu moga być następujące podmioty: władze publiczne wszystkich poziomów, instytucje publiczne, agencje rozwoju, wyższe uczelnie, instytuty badawcze, organizacje pozarządowe, stowarzyszenia, fundacje, firmy prywatne posiadające osobowość prawną, organizacje międzynarodowe. Minimalna liczba partnerów współdziałających $\mathrm{w}$ ramach projektu to wprawdzie 3 podmioty z 3 krajów, ale preferowane są w I naborze liczniejsze partnerstwa, zapewniające współpracę i efektywną wymianę doświadczeń z korzyścią dla każdego podmiotu. Rekomendowana liczba partnerów w projektach standardowych wynosi od 5 do 12 podmiotów, rekomendowany budżet to kwota z przedziału od 1,2 do 2,4 mln euro ze środków EFRR, natomiast czas realizacji to okres do 36 miesięcy.

Zalecane są konsultacje pomysłów na projekty przez platformę dla wnioskodawców ${ }^{2}$, przy czym im bardziej pomysły są dopracowane, tym lepiej. W szczególności zaawansowany proces tworzenia partnerstwa projektowego może być ważnym atutem pozytywnej oceny pomysłu. Do prowadzenia konsultacji upoważniony jest przyszły lider projektu. Z uwagi na duże zainteresowanie konsultacjami, jak wynika z dotychczasowych doświadczeń w tego

${ }_{1}^{1}$ Program Interreg Europa Środkowa, wraz z programami Interreg Region Morza Bałtyckiego i Interreg Europa, był prezentowany szczegółowo w: MAZOWSZE Studia Regionalne, 2021, nr 36, s. 169-178.

2 Applicant community. 
rodzaju programach, Wspólny Sekretariat dopuszcza jedną konsultację dla jednego pomysłu. Przygotowując projekt, warto skorzystać z dostępnego na stronie programu formularza aplikacyjnego offline. Wprowadzone do niego zapisy moga zostać następnie przeniesione do aplikacji „Jems”, która będzie tworzyć jedyną możliwość złożenia wniosku projektowego.

\section{Interreg Region Morza Bałtyckiego (IRMB)}

Program Interreg Region Morza Bałtyckiego 2021-2027 - drugi z programów współpracy transnarodowej - został oficjalnie uruchomiony już we wrześniu 2021 r., w ramach 12. dorocznego Forum Strategii UE dla Regionu Morza Bałtyckiego (SUE RMB). W stosunku do perspektywy 2014-2020, nie zmienia się zasadniczo zasięg geograficzny programu (z uczestnictwa zrezygnowały dwa północne regiony - państwa partnerskiego - Norwegii). Program będzie realizowany na obszarze 11 krajów, z których 8 to państwa członkowskie UE (Dania, Estonia, Finlandia, Litwa, Łotwa, Polska, Szwecja i część Niemiec) oraz 3 państwa partnerskie (Białoruś, część Norwegii i Rosji). Ze strony Białorusi konieczna jest deklaracja potwierdzająca udział w programie.

W ramach programu IRMB będą wspierane 4 priorytety oraz 9 celów szczegółowych. Trzy pierwsze priorytety dotyczą budowania społeczeństw: (1) innowacyjnych, (2) rozważnie korzystajacych z wody oraz (3) neutralnych dla klimatu. Ostatni priorytet (4) koncentruje się na zarządzaniu współpracą. Program jest skierowany do władz publicznych, organizacji otoczenia biznesu, wyspecjalizowanych agencji oraz dostawców infrastruktury i usług publicznych, jako głównych podmiotów odpowiedzialnych za transformację w kierunku odporniejszego i bardziej innowacyjnego regionu. Budżet programu wynosi 249,2 mln euro z EFRR.

Obecnie zaplanowane są 2 pierwsze nabory projektów, obejmujące trzy priorytety (1-3) i przynależne do nich cele szczegółowe. Nowością w programie jest podział projektów na główne (core): bez ograniczeń budżetowych (budżet proporcjonalny do zaplanowanych działań), z udziałem co najmniej 3 partnerów z 3 różnych krajów programu i czasem realizacji do 36 miesięcy, oraz projekty małe (small): do 500 tys. euro, z udziałem min. 3 partnerów z 3 różnych krajów programu i czasem realizacji do 24 miesięcy. Pierwsze nabory obejmą obie kategorie projektów. Ich oficjalne otwarcie, jak się przewiduje, nastapi 8 lutego $2022 \mathrm{r}$. Już od grudnia 2021 r. można natomiast konsultować ze Wspólnym Sekretariatem pomysły na projekty, opracowane na specjalnie w tym celu przygotowanym formularzu, udostępnionym na stronie programu. Wnioski o dofinansowanie projektów będą składane wyłącznie w systemie BAMOS+, do którego dostęp będzie możliwy po oficjalnym otwarciu naborów. Już teraz jednak partnerzy wiodący powinni zawnioskować o otrzymanie takiego dostępu.

\section{Interreg Europa (IE)}

Inauguracja programu współpracy międzyregionalnej Interreg Europa 2021-2027 miała miejsce w dniach 24-25 listopada 2021 r. w formule online. Podczas wydarzenia przekazano 
uczestnikom m.in. szereg informacji dotyczących I naboru wniosków, którego ogłoszenie zostało zaplanowane na 5 kwietnia 2022 r. Nabór potrwa do 31 maja $2022 \mathrm{r}$.

Program IE obejmuje całe terytorium Unii (UE-27) oraz Norwegię i Szwajcarię. Program ten służy poprawie efektywności polityk regionalnych w regionach o mniejszym doświadczeniu poprzez transfer wiedzy i dobrych praktyk z regionów dysponujących sprawdzonymi instrumentami. W programie przewidziany jest jeden priorytet „Lepsze zarządzanie współpraca" - wzrost kompetencji podmiotów odpowiedzialnych za tworzenie i wdrażanie polityk regionalnych. Zakres tematyczny dziedzin wsparcia pozostanie, jak dotychczas, szeroki i obejmie: bardziej konkurencyjną i inteligentną Europę, ekologiczne, niskoemisyjne przejście na gospodarkę bezemisyjna, Europę lepiej połączona, Europę bardziej społeczną i włączająca oraz Europę bliżej obywateli poprzez wspieranie zrównoważonego i zintegrowanego rozwoju wszystkich rodzajów terytoriów. Do udziału w projektach uprawnione są władze (krajowe, regionalne, lokalne) i instytucje publiczne oraz prywatne podmioty non-profit.

Z uwagi na cel realizacji projektów, jakim jest ich oddziaływanie na instrumenty polityki, jako obowiązkowy przyjęto udział w projektach „właścicieli” tych instrumentów, w formule partnerów stowarzyszonych (bez własnego budżetu). Oznacza to przykładowo, że partnerzy projektu odnoszący się do dokumentów regionalnych będą zobowiązani do zaproszenia/zaangażowania w projekt władz regionalnych jako partnerów stowarzyszonych. Trzeba pamiętać, że w każdym partnerstwie obowiązkowy jest udział partnerów z czterech stref geograficznych (Wschód, Zachód, Północ, Południe).

Budżet programu wynosi 379,5 mln euro z EFRR. Poziom dofinansowania z tego funduszu dla podmiotów publicznych obniży się w porównaniu z perspektywą 2014-2020 - z dotychczasowych 85 do $80 \%$, a dla partnerów non-profit wyniesie $70 \%$. Na I nabór zostanie przeznaczone $40 \%$ alokacji EFRR (ok. $130 \mathrm{mln}$ euro). W programie będzie można występować, co jest nowościa, o dofinansowanie działań pilotażowych. Będzie to możliwe zarówno na etapie składania wniosków, jak również w trakcie realizacji projektów. Jak wiadomo, istota pilotaży jest testowanie konkretnych proponowanych w projekcie rozwiązań.

Platforma learningowa ze wsparciem eksperckim na stronie internetowej programu zostanie utrzymana. Będzie ona stanowiła zarazem, tak jak dotychczas, bazę wiedzy i dobrych praktyk. Na platformie odbywają się także otwarte i bezpłatne webinaria tematyczne, np. poświęcone takim zagadnieniom, jak: zintegrowane strategie niskoemisyjne, przemysł 4.0 i transformacja cyfrowa MŚP czy dziedzictwo kulturowe w regionach górskich. Ponadto platforma służy tworzeniu się społeczności programu.

Na podstawie informacji przekazywanych podczas seminariów oraz publikowanych przez Ministerstwo Funduszy i Polityki Regionalnej www.ewt.gov.pl, jak również stron internetowych programów Interreg na lata 2021-2027: www.interreg-central.eu, www.interregeurope.eu, www.interreg-baltic.eu 


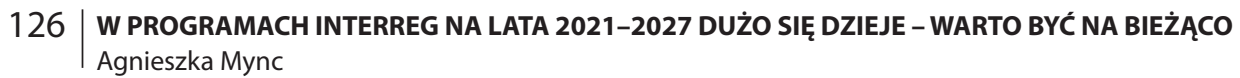

Agnieszka Mync - ekonomistka, specjalistka do spraw regionalnych, pracownik samorządowy z wieloletnim doświadczeniem w pracy na rzecz samorzq̨du województwa mazowieckiego.

Kontakt: Mazowieckie Biuro Planowania Regionalnego w Warszawie, ul. Nowy Zjazd 1, 00-301 Warszawa

e-mail:amync@mbpr.pl

Agnieszka Mync - economist, specialist in the field of regional issues, regional government employee of the Mazowieckie Voivodeship with many years of experience.

Contact: Mazovian Office for Regional Planning, ul. Nowy Zjazd 1, 00-301 Warszawa

e-mail:amync@mbpr.pl 